\title{
Observations of the Falling Motion of Plate-Like Snow Crystals
}

\author{
Part II: The Free-Fall Patterns and Velocity \\ Variations of Rimed Crystals
}

\author{
By Masahiro Kajikawa \\ Department of Earth Science, Akita University, Akita 010, Japan
}

and

Kyoichi Okuhara

Kamiyamada Elementary School, Kamiyamada-machi, Nagano Prefecture 389-08, Japan

(Manuscript received \& December 1996, in revised form 3 May 1997)

\begin{abstract}
Free-fall patterns and the variations in the vertical and horizontal velocities of rimed plate-like snow crystals were analysed by means of a stereo-photogrammetric method. The following main results were obtained:

1) Unstable fall patterns were classified into three types: nonrotation, swing, and rotation or spiral.

2) Considering the riming amount of crystals, the distinction among these types was approximately determined by the combination of the nondimensional moment of inertia (stability number) and the Reynolds number, which involves the mean vertical velocity.

3) The standard deviation of variation in vertical velocity was very small (less than about $3 \%$ of the mean vertical velocity). On the other hand, the standard deviation of variation in horizontal velocity was considerably large ( 4 to $15 \%$ of the mean vertical velocity).
\end{abstract}

Accordingly, it is likely that the variation of horizontal velocity plays an important role in the random aggregation of rimed plate-like snow crystals having almost the same shape and size.

\section{Introduction}

The aggregation of snow crystals to form snowflakes is an important process in the growth of precipitation particles in clouds. Detailed information on the falling motion of snow crystals in the atmosphere is required to investigate the aggregation process, as pointed out by Sasyo (1972) and Rogers (1974). The falling motion of snow crystals is attended with the horizontal motion and both vertical and horizontal velocity variations (Zikmunda and Vali, 1972; Kajikawa, 1992), which are responsible for an increase in the collision efficiency of snow crystals.

In a previous paper (Kajikawa, 1992), the free-fall pattern and velocity variation of unrimed plate-like snow crystals in still air were analyzed. This paper will focus on the correlations between the falling mo-

\footnotetext{
(C) 1997, Meteorological Society of Japan
}

tion and features of rimed plate-like snow crystals. The observation was carried out at the Mt.Teine Observatory (1024 m altitude) of Hokkaido University and the Mt. Hachimantai Observatory (1200 m altitude) of Akita University. The range of air temperature was -3.1 to $-11.2{ }^{\circ} \mathrm{C}$ in the observation period.

\section{Method of observation}

Since the method of measurement of falling motion is the same as in the previous paper (Kajikawa, 1992), the procedure will be described briefly. For the measurement of three-dimensional motion, a falling snow crystal was illuminated by a strobe light and photographed by means of a stereoscopic camera system. The coordinates of the snow crystal were calculated from successive corresponding points (the center of images) on the pair of pho- 
Table 1. The four types of unstable fall patterns of rimed plate-like snow crystals and the observed number of each type. The classification of the crystals follows the manner of Magono and Lee (1966).

\begin{tabular}{|c|c|c|c|c|}
\hline & Nonrotation & Swing & Rotation & Spiral \\
\hline Crystal Shape & $\uparrow$ & & & \\
\hline$\therefore$ Ric:Rimed plate or sector & 0 & 4 & 5 & 1 \\
\hline 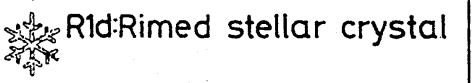 & 5 & 26 & 32 & 7 \\
\hline $\begin{array}{c}\text { R2a:Densely rimed plate } \\
\text { or sector }\end{array}$ & 7 & 4 & 6 & 1 \\
\hline $\begin{array}{l}\text { R2b:Densely rimed } \\
\text { stellar crystal }\end{array}$ & 4 & 21 & 19 & 7 \\
\hline $\begin{array}{l}\text { R3a:Graupellike snow } \\
\text { of hexagonal type }\end{array}$ & 11 & 2 & 1 & 0 \\
\hline $\begin{array}{c}\text { Total Number } \\
(\text { Rate, } \%)\end{array}$ & $27.6)$ & $\begin{array}{c}57 \\
(35.0)\end{array}$ & $\begin{array}{c}63 \\
(38.7)\end{array}$ & $\begin{array}{l}16 \\
(9.8)\end{array}$ \\
\hline $\begin{array}{c}\text { Unrimed Plate-Like Crystals } \\
(\text { Rate, } \%)\end{array}$ & $\begin{array}{c}15 \\
(27.8) \\
\end{array}$ & $\begin{array}{l}23 \\
(42.6) \\
\end{array}$ & $\begin{array}{c}13 \\
(24.1) \\
\end{array}$ & $\begin{array}{l}3 \\
(5.6)\end{array}$ \\
\hline
\end{tabular}

tographs. Considering possible factors related to errors in the analysis, it was concluded that the position of the crystals could be determined to the accuracy of $\pm 0.02 \mathrm{~cm}$ and $\pm 0.04 \mathrm{~cm}$ for the vertical and horizontal axes, respectively. The fallen snow crystals were caught in a laboratory dish filled with silicone oil and were microphotographed for determining shape, size, and mass. The fall velocity $\bar{V} z$ (mean vertical velocity) of individual snow crystals was previously described as a function of the size $d$ or mass $M$ (Kajikawa, 1975; Heymsfield and Kajikawa, 1987).

\section{Results}

\subsection{The free-fall pattern of rimed plate-like snow crystals}

All of the observed crystals exhibited unstable motion, which would be due to vortex shedding to the rear of the crystals, in the same manner as the tank experiment with circular disks (Willmarth et al., 1964; Stringham et al., 1969). As with the unrimed crystals (Kajikawa, 1992), there were three kinds of the unstable falling motion : the oscillation about an axis in the plane of the rimed plate-like crystals, the swing from side to side, and the rotation or spiral about a vertical axis. The tumbling motion did not appear in the present observations.

According to the horizontal movement of crystals, unstable fall patterns were classified into four types in the same way as the unrimed crystals (Kajikawa, 1992), as follows:

1) The nonrotation type which exhibits the falling motion without rotation about the vertical axis, but with horizontal movement roughly in a straight line.

2) The swing type having falling motion without rotation about the vertical axis, but with horizontal movement of a zigzag line.

3) The rotation type where crystals rotates about the vertical axis, with the horizontal movement traced as a part of an ellipse.

4) The spiral type where the falling motion shows rotation about the vertical axis, with horizontal movement of a spiral.

It should be noted that the rotation type approaches the spiral type with large amplitudes or long periods, if the observation of the falling motion is performed over a longer distance. The classified unstable fall patterns along with their observed number for each type are summarized in Table 1, including the data of unrimed crystals (Kajikawa, 1992) for the purpose of comparison. The rate of the rotation type is large, and in turn, the rates of the swing type and the nonrotation type are smaller than that of the unrimed crystals. The reason for this may be found in the difference in the degree of asymmetry of mass distribution. Namely, it appears likely that rimed crystals become more asymmetrical in shape than the unrimed crystals, as they capture a large amount of cloud droplets.

\subsection{Characteristics of the unstable fall pattern}

According to the results of tank experiments for the circular disk (Willmarth et al., 1964), it appears 


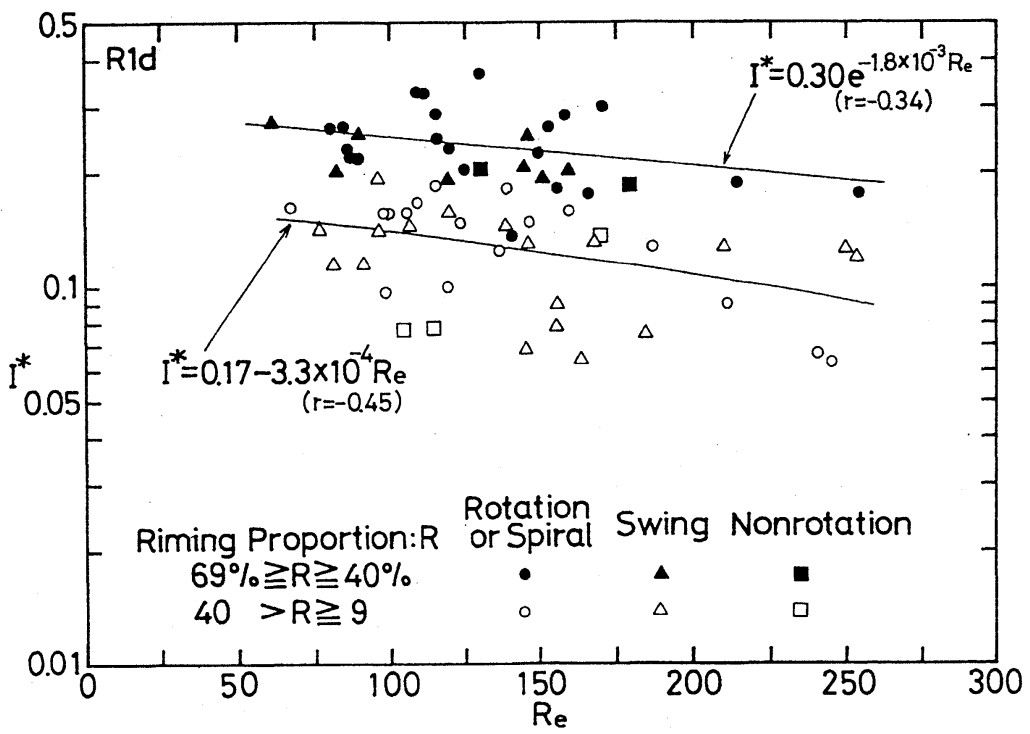

Fig. 1. The relationship between the stability number $I^{*}$ and the Reynolds number $R e$, considering the riming proportion $R$ for the rimed stellar crystals (R1d). The solid lines are the empirical equations with the correlation coefficient $r$ for the two groups divided by the riming amount of crystals.

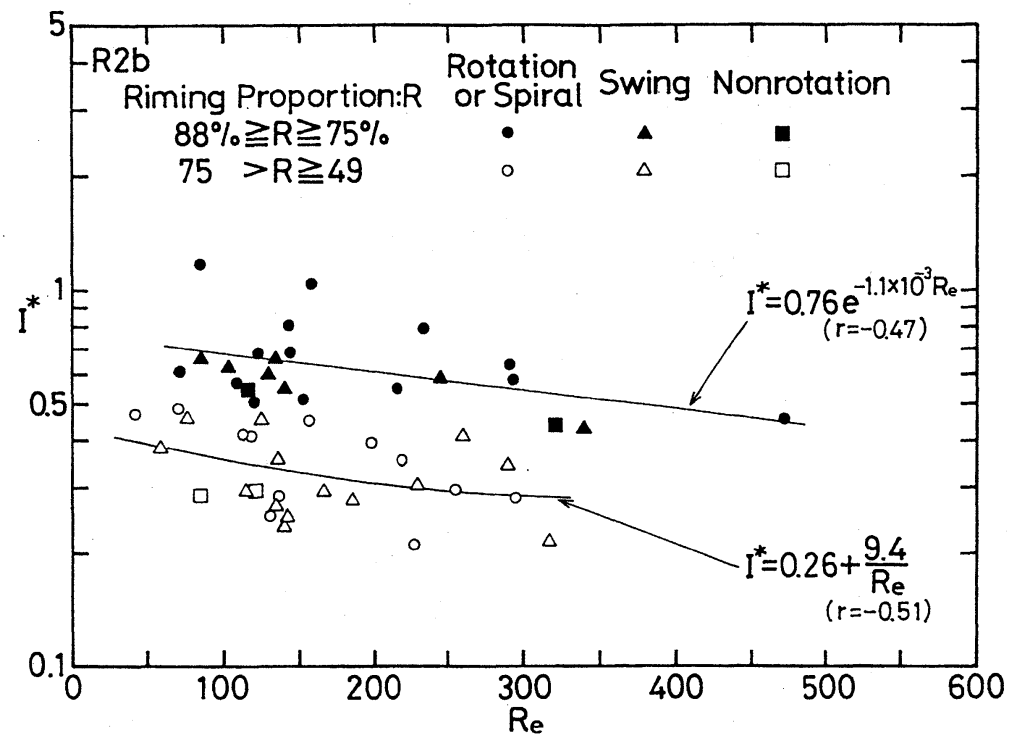

Fig. 2. The relationship between the stability number $I^{*}$ and the Reynolds number $R e$ for the densely rimed stellar crystals (R2b). The symbols are the same as Fig. 1, except the ranges of riming proportion.

that over the range of unstable falling motion as the values of Reynolds number $\operatorname{Re}(=\bar{V} z d / \nu)$ and the nondimensional moment of inertia $I^{*}\left(=I a / \rho d^{5}\right.$, stability number) of crystals increase, the more developed unstable patterns become. Here, $\nu$ is the kinematic viscosity of air, $I a\left(=M d^{2} / 16\right)$ the moment of inertia about the a-axis of crystals and $\rho$ the density of air. Thus the result of present observation can be approximately arranged by the combination of $R e$ and $I^{*}$, considering the riming proportion $R$, as shown in Figs. 1 and 2. In these figures, the data of rimed stellar crystals (R1d) and densely rimed stellar crystals (R2b) are shown, since their numbers are relatively abundant. $R(\%)$ is defined as the ratio of riming amount $\left(M-M_{o}\right)$ to $M$, according to Harimaya and Sato (1989). Here, $M_{o}$ is the 


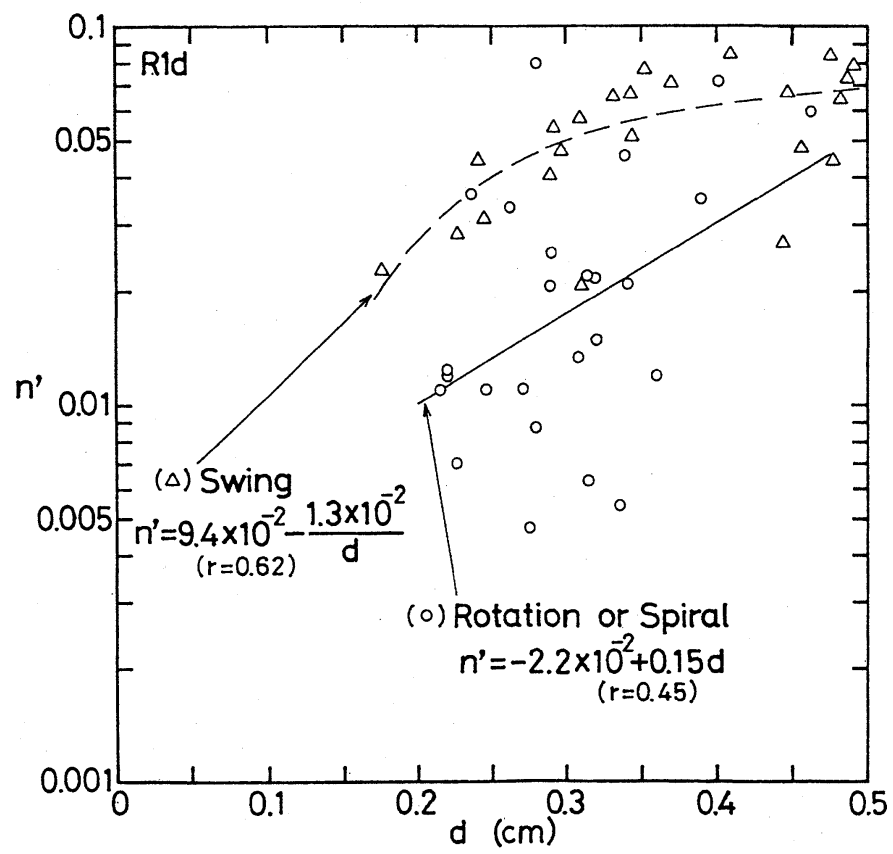

Fig. 3. The relationship between the nondimensional frequency $n^{\prime}$ and the size $d$ of R1d for the rotation or spiral and swing type.

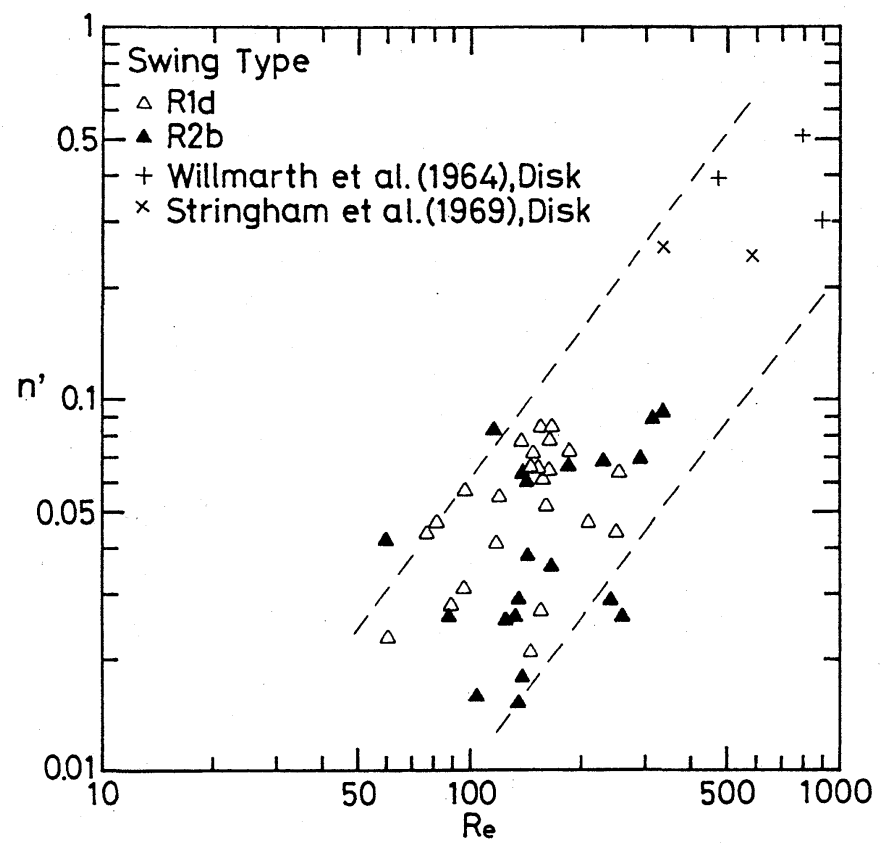

Fig. 4. The relationship between $n^{\prime}$ and $R e$ for the swing type including the results of tank experiments.

mean mass of unrimed dendritic crystals (P1e, P2a and P2c; Heymsfield and Kajikawa,1987). The solid lines in those figures indicate the empirical equations with the correlation coefficient $r$ obtained by the least-squares method. It can be seen in the individual group that the rate of rotation or spiral type increases in the large range of $I^{*}$.
Figure 3 shows the relationship between the nondimensional frequency $n^{\prime}(=n d / \bar{V} z)$ of the swing and rotation or spiral types and the size $d$ for R1d. Here, $n$ is the frequency of the swing and the rotation or spiral about the vertical axis. The solid and broken lines represent the empirical equations of $n^{\prime}$ as a function of $d$ for the rotation or spiral and the 
swing type, respectively. The value of $n^{\prime}$ increases with increase in $d$, although the large amount of scatter appear in $n^{\prime}$. The values of $n^{\prime}$ for the swing type are greater than those of the rotation or spiral type when holding $d$ constant.

The relationship between $n^{\prime}$ and $R e$ is shown in Fig. 4 for the swing type of rimed crystals (R1d and $\mathrm{R} 2 \mathrm{~b})$. It can be seen that $n^{\prime}$ exists in the extended range of the results of tank experiment for circular disk (Willmarth et al., 1964; Stringham et al., 1969).

Figure 5 shows the relationship between the nondimensional amplitude $a^{\prime}(=a / d)$ and $n^{\prime}$ of the swing and the rotation or spiral type for R2b. Here, $a$ is the amplitude of horizontal movement. As with the unrimed dendritic crystals (Kajikawa, 1992), $a^{\prime}$ is inversely proportional to $n^{\prime}$.

The relationship between $a^{\prime}$ and the mean horizontal velocity $\bar{V}_{H}$ is shown in Fig. 6 for R1d. It can be seen that $\bar{V}_{H}$ of the rotation or spiral type increases as $a^{\prime}$ increases. On the other hand, in the swing type there is a trend toward smaller $\bar{V}_{H}$ with increasing $a^{\prime}$. For the various factors of unstable fall patterns, the empirical equation selected when $r$ is relatively large is shown in Table 2 .

\subsection{Velocity variations of rimed snow crystals}

The degree of the velocity variation of rimed snow crystals can be expressed by the standard deviation of the velocity distribution for individual stereophotographs, using the same method that was applied to the early snowflakes by Kajikawa (1989). The standard deviation $\sigma_{z}$ of the vertical verocity $V_{z}$ is shown in Fig. 7 for R2b. Although $\sigma_{z}$ exhibits a slight increase with the mean vertical velocity $\bar{V}_{z}$, it is smaller than $3.5 \mathrm{~cm} \mathrm{~s}^{-1}$ (1 to $3 \%$ of $\bar{V}_{z}$ ). The broken line in this figure represents an empirical equation for the swing type having a relatively large correlation coefficient $(r=0.38)$. In the case of the rotation or spiral type, the empirical equation having relatively large $r$ is shown in Table 2 .

Figure 8 shows the relationship between the standard deviation $\sigma_{H}$ of the horizontal velocity $V_{H}$ and the mean horizontal velocity $\bar{V}_{H}$ for R1d. It can be seen that $\sigma_{H}$ increases as $\bar{V}_{H}$ increases and has a slight dependence on the type of unstable pattern. The values of $\sigma_{H}$ amount to about $50 \%$ of $\bar{V}_{H}$ or 4 to $15 \%$ of $\bar{V}_{z}$, and are considerably larger than $\sigma_{z}$.

From the results described above, it is likely that the variation of the horizontal velocity, in particular, plays an important role in the random aggregation process of rimed snow crystals having almost the same shape and size.

\section{Concluding remarks}

The falling motion of rimed plate-like snow crystals in still air was analyzed by means of a stereophotogrammetry. Unstable fall patterns were classified into three types: nonrotation, swing, and ro-

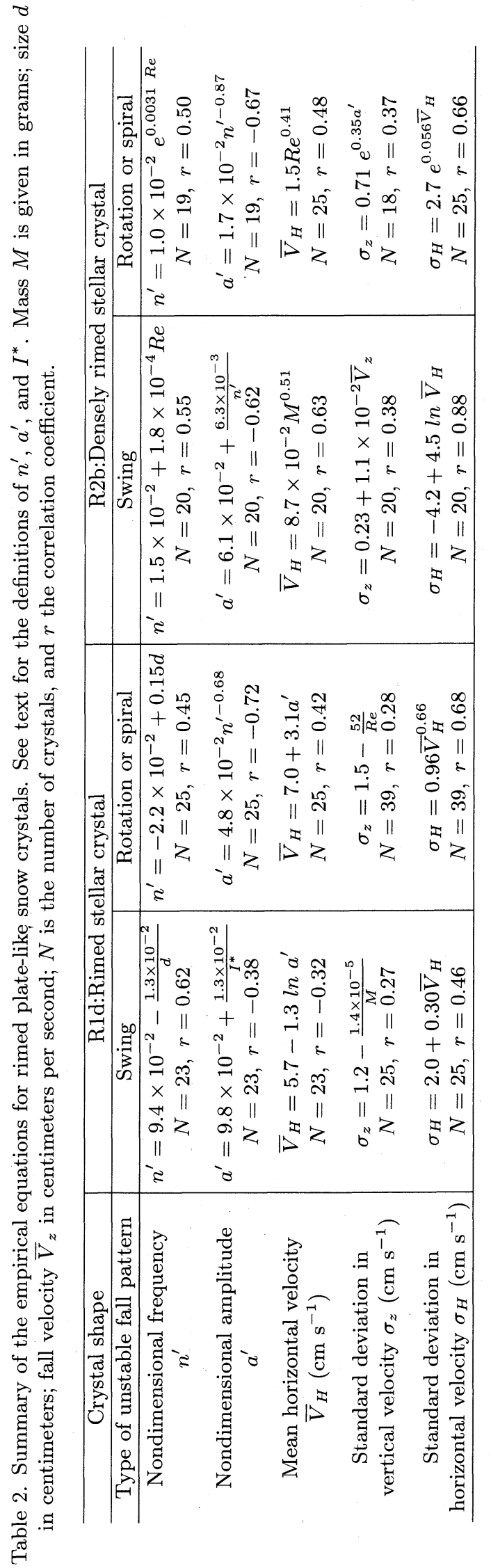




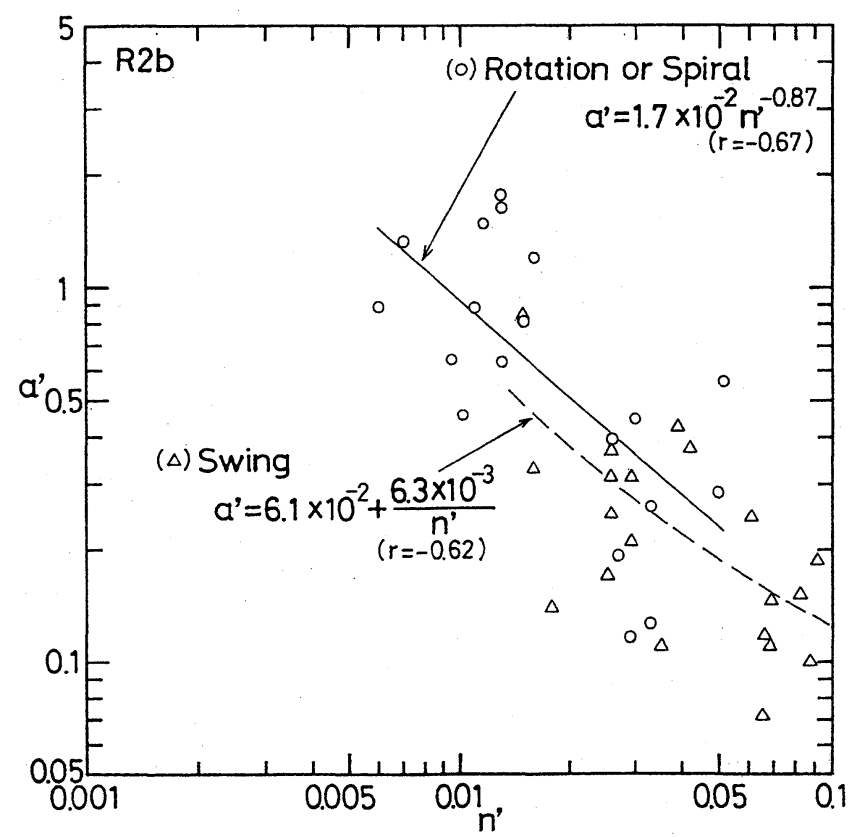

Fig. 5. The relationship between the non-dimensional amplitude $a^{\prime}$ and $n^{\prime}$ for R2b. The symbols are the same as in Fig. 3.

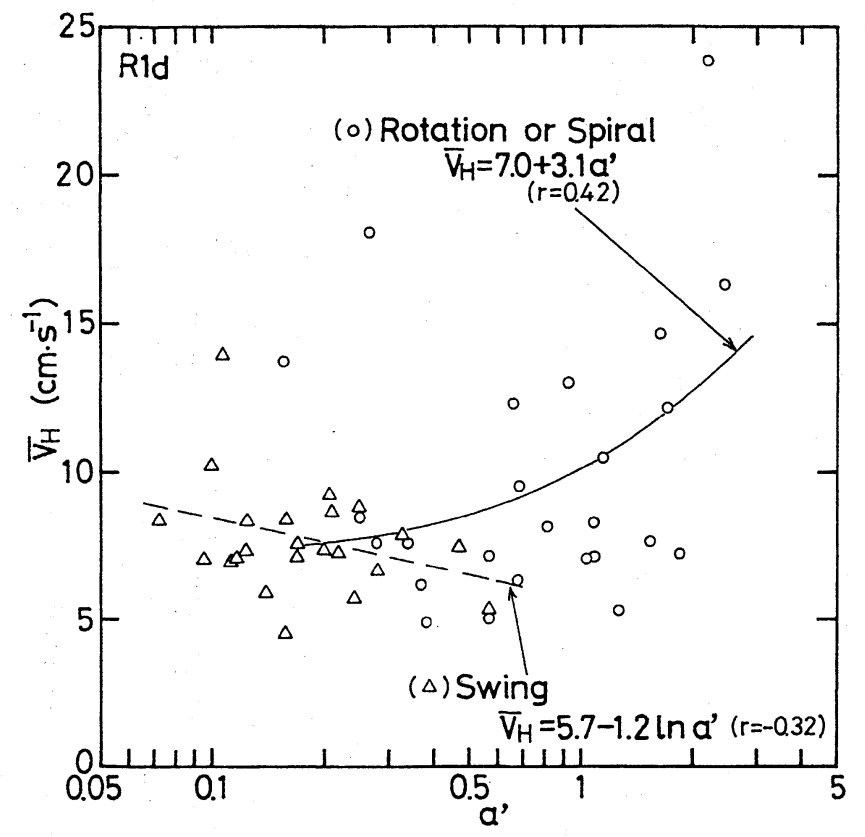

Fig. 6. The relationship between the mean horizontal velocity $\bar{V}_{H}$ and $a^{\prime}$ for R1d. The symbols are the same as in Fig. 3. 


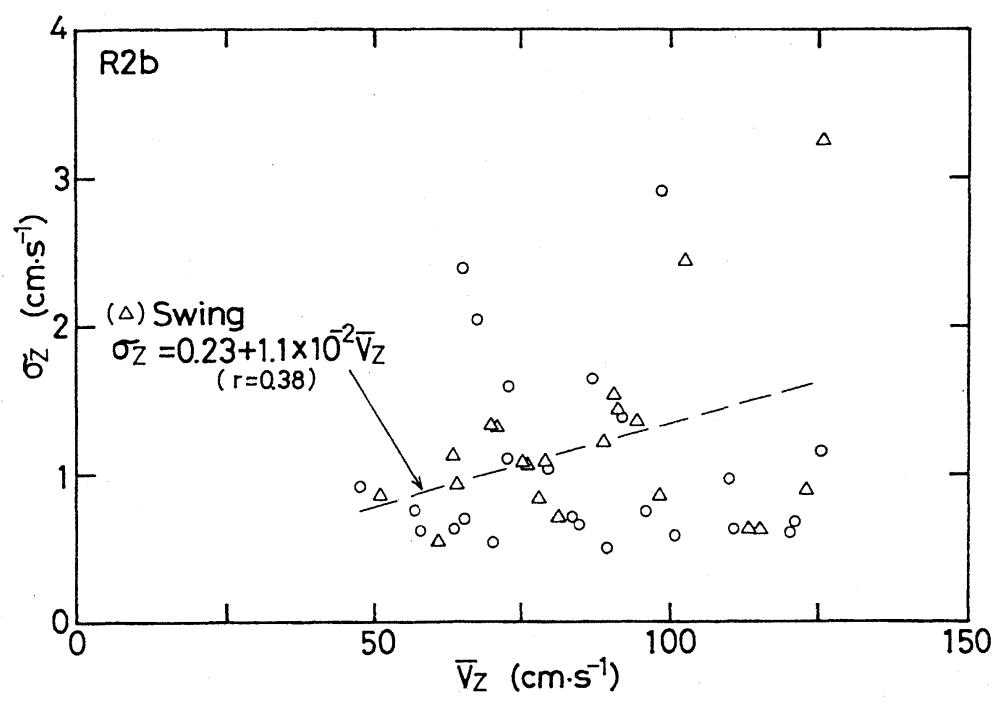

Fig. 7. The relationship between the mean vertical velocity (fall velocity) $\bar{V}_{z}$ and the standard deviation $\sigma_{z}$ of variation in vertical velocity for R2b. The symbols are the same as in Fig 3.

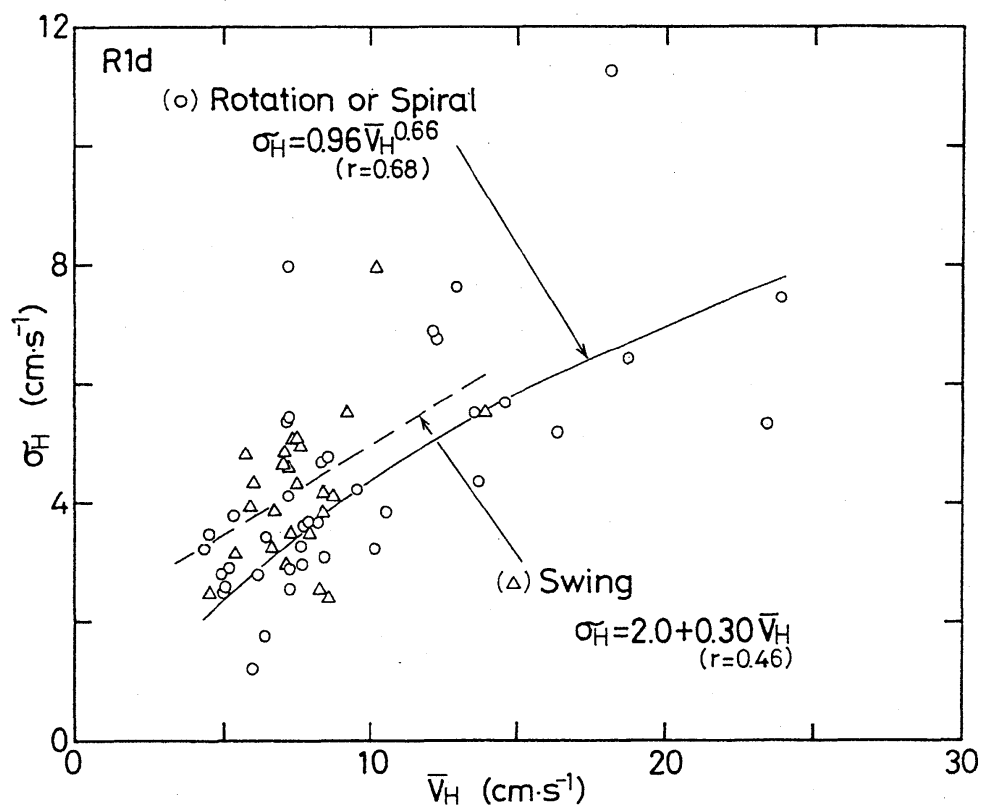

Fig. 8. The relationship between the mean horizontal velocity $\bar{V}_{H}$ and the standard deviation $\sigma_{H}$ of variation in horizontal velocity for R1d. The symbols are the same as in Fig. 3.

tation or spiral. These types were roughly distinguished by the combination of riming proportion, the nondimensional moment of inertia (stability number), and Reynolds number with respect to the fall velocity (mean vertical velocity) of crystals, as shown in Figs. 1 and 2 .

The standard deviation of variation in vertical velocity is less than about $3 \%$ of the fall velocity.
On the other hand, the standard deviation of variation in horizontal velocity is considerably large (4 to $15 \%$ of the fall velocity). Accordingly, it seems likely that the variation of horizontal velocity, in particular, plays an important role in random aggregation of rimed plate-like snow crystals having almost the same shape and size. The standard deviations of the velocities can be empirically estimated 
as functions of various factors (e.g., the fall velocity, size, mass, and nondimensional moment of inertia of rimed crystals), as shown in Table 2.

\section{Acknowledgements}

The authors are very grateful to Prof. K. Kikuchi, Hokkaido University for permission to use the Mt. Teine Observatory for this study. Partial funding for this study was provided by a Grant-in Aid for Scientific Research (C) of the Ministry of Education, Science, Sports and Culture of Japan.

\section{References}

Harimaya, T. and M. Sato, 1989: Measurement of the riming amount on snow flakes. J. Fac. Sci., Hokkaido Univ., Ser VII, 8, 355-366.

Heymsfield, A.J. and M. Kajikawa, 1987: An improved approach to calculating terminal velocities of platelike crystals and graupel. J. Atmos. Sci., 44, 10881099.

Kajikawa, M., 1975: Experimental formula of falling velocity of snow crystals. J. Meteor. Soc. Japan, 53, $267-275$.

Kajikawa, M., 1989: Observation of the falling motion of early snowflakes. Part II: On the variation of falling velocity. J. Meteor. Soc. Japan, 67, 731-738.

Kajikawa, M., 1992: Observations of the falling motion of plate-like snow crystals. Part I: The free-fall patterns and velocity variations of unrimed crystals. $J$. Meteor. Soc. Japan, 70, 1-9.

Magono, C. and C.W. Lee, 1966: Meteorological classification of natural snow crystals. J. Fac. Sci., Hokkaido Univ., Ser. VII, 2, 321-335.

Rogers, D.C., 1974: The aggregation of natural ice crystals. Rep. No. AR 110, Dept. Atmos. Resources, Univ. of Wyoming, $35 \mathrm{pp}$.

Sasyo, Y., 1972: Study of the formation of precipitation by the aggregation of snow particles and the accretion of cloud droplets on snowflakes. Pap. Meteor. Geophys., 22, 69-142.

Stringham, G.E., D.B. Simons and H.P. Guy, 1969: The behavior of large particles falling in quiescent liquids. Geol. Survey Prof. Paper, 562-C, Washington, D.C., Government Printing Office, $36 \mathrm{pp}$.

Willmarth, W.W., N.E. Hawk and R.L. Harvey, 1964: Steady and unsteady motions and wakes of freely falling disks. Phys. Fluids, 7, 197-208.

Zikmunda, J. and G. Vali, 1972: Fall patterns and fall velocities of rimed ice crystals. J. Atmos. Sci, , 29, 1334-1347.

板状雪結晶の落下運動の観測

第 2 部：雲粒付結晶の自由落下パターンと速度変動

\author{
梶川正弘 \\ (秋田大学教育学部地学教室) \\ 奥原京一 \\ （長野県上山田町上山田小学校）
}

\begin{abstract}
雲粒付の 板状雪結晶について、自由落下パターンと落下速度の鉛直および水平成 分の変動を立体写真 法により観測した。

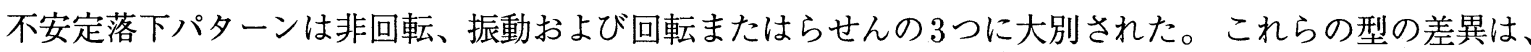
結晶の雲粒付着量を考虑すると、無次元慣性モーメントと平均落下速度に関するレイノルズ数の組み合わ せに依存していた。

鉛直成分の変動の標準偏差は小さく、平均落下速度の約 $3 \%$ 以下であった。一方、水平成分の変動の標 準偏差はかなり大きかった(平均落下速度の約 4 15\%)。従って、ほほ同じ形とサイズの雲粒付の板状雪 結晶の不規則集合過程に拉いては、落下速度の水平成分の変動が重要な役割をしていると考えられる。
\end{abstract}

